\title{
Soil fertility status and wheat nutrient content in Vertisol cropping systems of central highlands of Ethiopia
}

\author{
Hillette Hailu ${ }^{1,5^{*}}$, Tekalign Mamo ${ }^{2}$, Riikka Keskinen ${ }^{3}$, Erik Karltun ${ }^{4}$, Heluf Gebrekidan ${ }^{5}$ and Taye Bekele ${ }^{6}$
}

\begin{abstract}
Background: Land degradation reduces agricultural productivity and poses a serious threat on food security status of households. In Ethiopia, farmers have been using only urea and di-ammonium phosphate for more than 15 years. Several reports that indicate lack of response to these fertilizers, which could be due to limitation of nutrients other than nitrogen and phosphorus. Therefore, the present study was initiated to evaluate the soil fertility status of ten sites in central highlands Vertisols of Ethiopia and wheat nutrient content.

Results: The physico-chemical properties of soils showed that the soils were clayey in texture, neutral to slightly alkaline (pH 7.2-7.9) and low to medium in their organic matter (1.6-3.2 \%) content. Total N content was low in $100 \%$ of the samples while $80 \%$ of the soil samples showed P deficiency $\left(<10 \mathrm{mg} \mathrm{kg}^{-1}\right)$. Exchangeable $\mathrm{K}, \mathrm{Ca}$ and $\mathrm{Mg}$ in all soil samples were high, while available sulfur was low. On the other hand, K to Mg ratio varied from 0.13:1 to 0.44:1, indicating $\mathrm{Mg}$ induced $\mathrm{K}$ deficiency. All soil samples were adequate when analyzed by ammonium bicarbonate diethylene tri-amine penta-acetic acid extractable $\mathrm{Cu}\left(>0.5 \mathrm{mg} \mathrm{kg}^{-1}\right)$, Fe $\left(>5 \mathrm{mg} \mathrm{kg}^{-1}\right)$, and $\mathrm{Mn}\left(>1 \mathrm{mg} \mathrm{kg}^{-1}\right)$ contents. However, $70 \%$ of the samples were deficient in $\mathrm{Zn}\left(<1.5 \mathrm{mg} \mathrm{kg}^{-1}\right)$ content. Mehlich 3 extractable $\mathrm{B}\left(<0.5 \mathrm{mg} \mathrm{kg}^{-1}\right)$ and acid ammonium oxalate extractable Mo $\left(<0.1 \mathrm{mg} \mathrm{kg}^{-1}\right)$ were found to be low in all soil samples. The plant analysis data showed that all samples were low in N, P and K, while high in $\mathrm{Ca}$ and $\mathrm{Mg}$ concentrations. The deficiency of tissue K content was not predicted by the soil exchangeable K test. Plant micronutrient analysis showed that $\mathrm{Cu}$, Fe, $\mathrm{Mn}$ and $\mathrm{Cl}$ concentrations were within the sufficiency range while $\mathrm{Zn}$ was deficient in all of the samples.

Conclusions: Soil and/or tissue test results are indicative of deficiency of N, P, K, S, Zn, B and Mo that could be amended by fertilizer application, although more data are needed to thoroughly support this conclusion. The highest correlation ( $r>0.90$ ) between soil and plant nutrient content was observed for P, K, Mg, Cu, Fe, Mn and Zn, implying that flag leaves at flowering stage can be used to calibrate soil and plant contents for the deficient nutrients.
\end{abstract}

Keywords: Soil, Plant, Nutrient, Soil fertility, Deficient, Adequate, Fertilizer

\section{Background}

In Ethiopia, agriculture is the mainstay of the majority of the population and major driver of the national economy. Agricultural production has been highly dependent on natural resources for centuries [1]. However, increased human population and other factors have degraded the natural resources in the country thus seriously

\footnotetext{
*Correspondence: hillette16@gmail.com

${ }^{5}$ College of Agriculture and Environmental Sciences, Haramaya

University, Haramaya, Ethiopia

Full list of author information is available at the end of the article
}

threatening sustainable agriculture and food security $[2,3]$. Continuous cropping and inadequate replacement of nutrients removed in harvested materials or lose through erosion and leaching has been the major causes of soil fertility decline [4]. This is particularly evident in the intensively cultivated areas, traditionally called high-potential areas that are mainly concentrated in the highlands of Ethiopia. To tackle this problem, the country initiated community-based participatory watershed management [5], and to date, it has rehabilitated millions of hectares of degraded land. 
Soil nutrient depletion in smallholder farming systems is recognized as a causal force leading to food insecurity and rural poverty in Africa [6, 7]. The rate of annual soil macronutrient depletion in Africa was estimated at $22 \mathrm{~kg} \mathrm{~N} \mathrm{ha}^{-1}, 2.5 \mathrm{~kg} \mathrm{P} \mathrm{ha}^{-1}$ and $15 \mathrm{~kg} \mathrm{~K} \mathrm{ha}^{-1}$ over 30 years of no use or insufficient use of fertilizers [8]. In Ethiopia, the depletion rate of macronutrients, $122 \mathrm{~kg} \mathrm{~N} \mathrm{ha}^{-1}$ year $^{-1}, 13 \mathrm{~kg} \mathrm{P} \mathrm{ha}^{-1}$ year $^{-1}$ and $82 \mathrm{~kg} \mathrm{~K} \mathrm{ha}^{-1}$ year $^{-1}$, was estimated to be high [9]. Decline in soil fertility due to long-term cultivation with little or no fertilizer additions is the major form of land degradation in most of sub-Saharan Africa. Declining soil fertility has also been stressed to be the fundamental impediment to agricultural development and the major reason for the slow growth in food production in Ethiopia [10]. The loss of soil nutrients in Ethiopia is related to cultural practices such as low fertilizer use, removal of vegetative cover (such as straw or stubble) and burning plant residues or the annual burning of vegetation on grazing land [11]. An average quantity of di-ammonium phosphate (DAP) and urea of $57 \mathrm{~kg} \mathrm{ha}^{-1}$ was consumed over the period of 1995 to 2008 for wheat production [12].

Soil degradation is common also in Ethiopian Vertisols, which cover about 13 Mha of land. Ethiopia ranks third in Vertisols abundance in Africa after Sudan and Chad [13]. More than half (8.6 Mha) of the Vertisols are found in the central highlands with altitude of more than 1500 meters above sea level (masl) [13, 14]. About $25 \%(1.9$ Mha) of the Vertisols occurring in the highlands are cultivated [15]. The crops that are commonly grown on Vertisols of Ethiopia are teff, bread wheat, barley, chickpea, lentil and niger seed [16]. Recently, farmers in Ethiopia are using modified plough called broad bed maker (BBM) and harvesting higher yields from multiple crops on the same plot of land per season [17].

Previously, only nitrogen $(\mathrm{N})$ and phosphorus $(\mathrm{P})$ were considered to be the limiting nutrients in Vertisols of Ethiopia [18]. However, many soils in the highlands of Ethiopia are poor in available plant nutrients and organic matter content [19]. Recently, the results of national soil fertility mapping initiative has also indicated that other nutrients including $\mathrm{K}, \mathrm{S}, \mathrm{Fe}, \mathrm{Zn}$ and $\mathrm{B}$ are also found to be deficient in these soils [20]. In addition to the high fixing characteristics of Vertisols [21], lack of response to P application on central highland Vertisols of Ethiopia may be due to deficiency of nutrients other than $P$.

Soil tests are commonly used to assess the sufficiency or deficiency of essential plant nutrients. Although soil tests provide information about a soil's ability to supply plant available nutrients, it is an indirect measurement. Plant analysis, on the other hand, reveal the nutritional status of the plant directly and when combined with the soil tests can be used to evaluate the nutritional sufficiency of the soil-plant system and further to design corrective treatments [22]. Therefore, this study was initiated with the objectives of identifying nutrient limitations through soil analysis and wheat nutrient status. The results of the study serve in making suggestions on improving fertilization and soil management to achieve sustainable crop production on Vertisols of the central highlands of Ethiopia.

\section{Methods}

\section{Description of sampling locations}

Surface soil $(0-15 \mathrm{~cm})$ and wheat leaf samples were taken from ten sites of central highland Vertisols listed in Table 1. Global Positioning System (GPS) was used to identify the geographical locations (Additional file 1: Figure S1).

\section{Traditional farming practices of wheat growers}

Information regarding farming practices of farmers at the sampling sites is presented in Table 2. Farmers have been using only two types of fertilizers for more than 15 years, urea $(46 \% \mathrm{~N})$ and DAP $\left(18 \% \mathrm{~N}, 46 \% \mathrm{P}_{2} \mathrm{O}_{5}\right)$. They usually apply one-third and two-thirds of the nitrogen dose at sowing and tillering stage, respectively. They use broad bed maker (BBM), which is an oxen-drawn traditional wooden plough, modified for the construction of raised beds and furrows to facilitate surface drainage through the furrows between the beds so as to grow crops on the beds [23]. The improved bread wheat variety Digalu (HAR-3116) was the most common cultivar cultivated in the study sites.

\section{Soil and plant sampling}

Twelve composite surface soil $(0-15 \mathrm{~cm})$ samples were collected from each wheat fields at the sampling locations. Each composite soil sample comprised of 15 sub

\section{Table 1 Sampling locations and site characteristics}

\begin{tabular}{llll}
\hline Location (District) & Latitude (N) & Longitude (E) & Altitude (m) \\
\hline Akaki (Mereno) & $8^{\circ} 52^{\prime} 1^{\prime \prime}$ & $38^{\circ} 47^{\prime} 1^{\prime \prime}$ & 2400 \\
Ambo (Kisole Odoliva) & $8^{\circ} 59^{\prime} 2^{\prime \prime}$ & $37^{\circ} 51^{\prime} 30^{\prime \prime}$ & 2104 \\
Chefe Donsa (Haberu & $8^{\circ} 57^{\prime} 60^{\prime \prime}$ & $39^{\circ} 06^{\prime} 28^{\prime \prime}$ & 2444 \\
$\quad$ Sefetu) & & & \\
Debre Zeit (Denkaka) & $8^{\circ} 41^{\prime} 36^{\prime \prime}$ & $39^{\circ} 03^{\prime} 17^{\prime \prime}$ & 1880 \\
Ginchi (Jemjem Legebatu) & $9^{\circ} 3^{\prime} 37^{\prime \prime}$ & $38^{\circ} 07^{\prime} 11^{\prime \prime}$ & 2200 \\
Holeta (Guntuta) & $9^{\circ} 3^{\prime} 58^{\prime \prime}$ & $38^{\circ} 29^{\prime} 53^{\prime \prime}$ & 2415 \\
Mojo (Ajere Wolkite) & $8^{\circ} 47^{\prime} 41^{\prime \prime}$ & $39^{\circ} 16^{\prime} 2^{\prime \prime}$ & 2275 \\
Sheno (Wentu) & $9^{\circ} 24^{\prime} 16^{\prime \prime}$ & $39^{\circ} 21^{\prime} 23^{\prime \prime}$ & 2911 \\
Tullu Bolo (Awash Bune) & $8^{\circ} 38^{\prime} 56^{\prime \prime}$ & $38^{\circ} 07^{\prime} 23^{\prime \prime}$ & 2115 \\
Woliso (D/Kora) & $8^{\circ} 50^{\prime} 50^{\prime \prime}$ & $38^{\circ} 48^{\prime} 37^{\prime \prime}$ & 2090 \\
\hline
\end{tabular}


Table 2 Fertilizer application rates and previous year cropping history of wheat growers in central highlands of Ethiopia

\begin{tabular}{llll}
\hline Location (District) & \multicolumn{2}{l}{ Fertilizer used } & Previous crop \\
\cline { 2 - 3 } & $\mathbf{N}\left(\mathbf{k g ~ h a} \mathbf{~}^{\mathbf{- 1}} \mathbf{)}\right.$ & $\mathbf{P} \mathbf{( k g ~ h \mathbf { ~ h } ^ { \mathbf { - 1 } } \mathbf { ) }}$ & \\
\hline Akaki (Mereno) & 60 & 20 & Wheat \\
Ambo (Kisole Odoliva) & 65 & 20 & Teff \\
Chefe Donsa (Haberu Sefetu) & 86 & 25 & Lentil \\
Debre Zeit (Denkaka) & 90 & 25 & Lentil \\
Ginchi (Jemjem Legebatu) & 75 & 20 & Teff \\
Holeta (Guntuta) & 78 & 20 & Lentil \\
Mojo (Ajere Wolkite) & 83 & 30 & Teff \\
Sheno (Wentu) & 60 & 30 & Wheat \\
Tullu Bolo (Awash Bune) & 63 & 30 & Teff \\
Woliso (D/Kora) & 62 & 25 & Teff \\
\hline
\end{tabular}

samples collected in a zigzag pattern within each block and mixed thoroughly following a standard procedure for soil sampling and sample preparation [24]. Six composite flag leaf samples were collected from each field of the sampling sites. Each composite leaf sample comprised 150 randomly selected flag leaves at flowering stage. A total of 120 surface soil $(0-15 \mathrm{~cm})$ and 60 composite leaf samples were taken from the studied sites. The area of each experimental field in all sites was about 1 ha.

\section{Soil and plant analysis}

Laboratory analyses were conducted at Debre Ziet Agricultural Research Center, Ethiopia and at Natural Resources Institute Finland (former MTT Agri food Research Finland) using the following standard methods. Soil particle size distribution was determined by hydrometer method [25]. Soil $\mathrm{pH}$ and electrical conductivity (EC) were measured in soil:water extract (1:2.5) according to Rhoades [26]. $\mathrm{CaCO}_{3}$ content was determined using the calcimeter method according to Black [27]. Soil organic carbon (C) and total nitrogen $(\mathrm{N})$ content were determined by dry combustion methods based on ISO 10694 [28] and ISO 13878 [29] protocols, respectively. Soil organic matter was calculated by multiplying soil organic carbon by 1.724 assuming average $\mathrm{C}$ concentration of organic matter of $58 \%$. Available phosphorus was extracted by $0.5 \mathrm{~N}$ sodium bicarbonate solution as described by Olsen et al. [30], and thereafter measured using Perkin Elmer Optima 8300 Inductively Coupled Plasma-Optical Emission Spectrometer (ICP-OES). Sulfate was determined in the soil extract by the turbidity method using spectrophotometer on transmittance at a wave length of $420 \mathrm{~nm}$ according to Williams and Steinbergs [31].
One molar neutral ammonium acetate $(\mathrm{pH}=7)$ was used to extract the exchangeable cations $(\mathrm{Ca}, \mathrm{Mg}, \mathrm{K}$ and $\mathrm{Na}$ ) [32]. Cations were then determined using ICPOES. Available micronutrients $(\mathrm{Cu}, \mathrm{Fe}, \mathrm{Mn}$ and $\mathrm{Zn})$ were extracted with ammonium bicarbonate di-ethylene tri-amine penta-acetic acid (AB-DTPA) as described by Soltanpour and Schwab [33] and were measured by ICP-OES. Mehlich 3 extraction was accomplished by mixing $2.5 \mathrm{~g}$ of soil and $25 \mathrm{ml}$ of Mehlich 3 solution [0.2 $\mathrm{M}$ acetic acid $\left(\mathrm{CH}_{3} \mathrm{COOH}\right), 0.25 \mathrm{M}$ ammonium nitrate $\left(\mathrm{NH}_{4} \mathrm{NO}_{3}\right), 0.015 \mathrm{M}$ ammonium fluoride $\left(\mathrm{NH}_{4} \mathrm{~F}\right)$, $0.013 \mathrm{M}$ nitric acid $\left(\mathrm{HNO}_{3}\right)$, and $0.001 \mathrm{M}$ ethylene diamine tetra-acetic acid (EDTA)], shaking for $5 \mathrm{~min}$, and filtering through a blue ribbon filter paper [34]. The filtrate was analyzed for available boron using ICPOES. Molybdenum was extracted with acid ammonium oxalate $(\mathrm{pH}=3)$ solution [35] and then analyzed using ICP-OES.

Leaves were first washed with distilled water, oven dried at $60-70{ }^{\circ} \mathrm{C}$ to a constant weight, ground, passed through $2-\mathrm{mm}$ sieve and placed in paper bags. Total nitrogen in plants was determined using Kjeldahl digestion procedure as described by Bremner and Mulvaney [36]. Plant digests (using concentrated $\mathrm{HNO}_{3}$ and $30 \%$ $\mathrm{H}_{2} \mathrm{O}_{2}$ ) were prepared and analyzed for $\mathrm{Ca}, \mathrm{Mg}, \mathrm{Cu}, \mathrm{Fe}$, $\mathrm{Mn}$ and $\mathrm{Zn}$ using Atomic Absorption Spectrophotometer while $P$ concentration of the digests was measured with a spectrophotometer and the $\mathrm{K}$ concentration with a flame photometer using required standard solutions. Plant chloride was determined by TRAACS 800 Analyzer using deionized water as an extractant [37].

\section{Statistical analysis}

Descriptive statistics was applied for calculation of means and standard errors. Correlation analysis was performed to assess relationships among soil and plant nutrient contents.

\section{Results and discussion \\ Soil characteristics \\ Particle size distribution}

The results of soil texture, as presented in Table 3 revealed that the particle size distribution of the surface soil $(0-15 \mathrm{~cm})$ of all the experimental sites was dominated by clay (above $53 \%$ ) except at Sheno (47 \%).The relatively high clay contents observed in this study agree with the findings of Kamara et al. [38] and Lemma and Smit [39], who also reported clay level of above $50 \%$ in Ginichi, central highlands Vertisols of Ethiopia. This is further supported by Debele [14] and Tesgaye [40], who reported that Vertisols in Ethiopian generally contain more than $40 \%$ clay in the surface horizon. 
Table 3 Particle (sand, silt and clay) size analysis and textural classes of the study sites $(n=12)$

\begin{tabular}{lllll}
\hline Location (District) & \% Sand & \% Silt & \% Clay & Textural class \\
\hline Akaki (Akaki) & $15^{\mathrm{a}}(0.43)^{\mathrm{b}}$ & $19(0.73)$ & $67(0.2)$ & Heavy clay \\
Ambo (Kisole Odoliva) & $18(0.35)$ & $16(0.7)$ & $66(0.88)$ & Heavy clay \\
Chefe Donsa (Haberu & $22(0.57)$ & $25(0.47)$ & $54(0.6)$ & Clay \\
$\quad$ Sefetu) & & & & \\
Debre Zeit (Denkaka) & $16(0.3)$ & $18(0.2)$ & $66(0.4)$ & Heavy clay \\
Ginichi (Jemjem Lege- & $22(0.47)$ & $20(0.77)$ & $57(1.1)$ & Clay \\
$\quad$ batu) & & & & \\
Holeta (Guntuta) & $21(0.38)$ & $20(0.48)$ & $59(0.47)$ & Clay \\
Mojo (Ajere Wolkite) & $19(1.3)$ & $18(1.2)$ & $63(0.5)$ & Heavy clay \\
Sheno (Wentu) & $23(0.37)$ & $30(0.89)$ & $47(0.91)$ & Clay \\
Tullu Bolo (Awash Bune) & $17(0.4)$ & $24(0.4)$ & $59(0.37)$ & Clay \\
Woliso (D/Kora) & $25(0.73)$ & $22(0.49)$ & $53(0.91)$ & Clay \\
\hline
\end{tabular}

a Indicate mean

b Indicate standard error in parentheses

\section{Soil $p H$ and EC}

As per the ratings for Ethiopian soils by Murphy [41] and Taddese [42], the soil $\mathrm{pH}$ was found to range from neutral to slightly alkaline with $\mathrm{pH}$ ranging from 7.2 to 7.9 (Table 4). Similar results were obtained by Debele [14] and Kebede and Charles [43].This $\mathrm{pH}$ range is favorable for most crops [42, 44]. The electrical conductivity ranged from 0.1 to $0.22 \mathrm{dSm}^{-1}$ in surface soil samples indicating that these soils have a low content of soluble salts and that there is no danger of salinity (Table 4).

\section{Soil organic matter and $\mathrm{C}$ to $\mathrm{N}$ ratio}

The organic matter contents were in the range of 1.6$3.2 \%$ on the surface soils (Table 4 ). These values fall under low to moderate range based on the ratings of soil test values established by Taddese [42].The values are similar to most cultivated soils of Ethiopia [38, 45] which is attributed to land use history such as complete removal of biomass from the field and rapid rate of mineralization [46]. The $\mathrm{C}$ to $\mathrm{N}$ ratio of the surface soil samples varied from 10 to 15 (Table 4), which is within the normal range for arable soil [47].

\section{Total N}

Data on total nitrogen of the surface soils are presented in Table 4. Total nitrogen levels between 0.1 and $0.2 \%$ are taken as low while those below $0.1 \%$ are very low for tropical soils [48]. It, therefore, follows that soils of the study areas are low to very low in their total nitrogen status. Total nitrogen closely followed the trend of organic matter. Generally, a site low in organic matter was also low in total nitrogen. This supports earlier studies in the area by Debele [14] and Beyene [49]. One of the characteristic features of tropical environment is its high temperature which leads to rapid loss of soil organic matter due to volatilization. Soil erosion due to steep slopes and heavy rainfall as well as leaching, may have contributed to nitrogen loss. Certainly, it is one of the most deficient elements in the tropics for crop production [11, 50, 51]. Under local conditions, in addition to the above factors, continuous crop removal also contributes the low organic matter content in the study areas.

\section{Available $P$}

Available P (Olsen extractable) in the studied sites varied between 3.8 and $14.6 \mathrm{mg} \mathrm{kg}^{-1}$ (Additional file 2: Figure S2). It was found to be deficient $\left(<10 \mathrm{mg} \mathrm{kg}^{-1}\right)$ and medium (between 10 and $17 \mathrm{mg} \mathrm{kg}^{-1}$ ) in 80 and $20 \%$ of the samples, respectively, when compared with the values

Table 4 Soil pH, electrical conductivity (EC), soil organic matter (SOM), total carbon(TC), total nitrogen (TN), carbon to nitrogen ratio(C:N) and sulfate-S content of the study sites $(n=12)$

\begin{tabular}{|c|c|c|c|c|c|c|c|}
\hline Location (District) & $\mathrm{pH}(1: 2.5)$ & $\begin{array}{l}\mathrm{EC}(1: 2.5) \\
\mathrm{dS} / \mathrm{m}\end{array}$ & $\begin{array}{l}\text { SOM } \\
(\%)\end{array}$ & $\begin{array}{l}\text { TC } \\
(\%)\end{array}$ & $\begin{array}{l}\text { TN } \\
(\%)\end{array}$ & $\mathrm{C}: \mathrm{N}$ & $\begin{array}{l}\mathrm{SO}_{4}-\mathrm{S} \\
\left(\mathrm{mg} \mathrm{kg}^{-1}\right)\end{array}$ \\
\hline Akaki (Akaki) & $7.4^{a}(0.01)^{b}$ & $0.149(0.014)$ & $1.9(0.005)$ & $1.2(0.003)$ & $0.1(0.0003)$ & $12.3(0.06)$ & $1.8(0.06)$ \\
\hline Ambo (Kisole Odoliva) & $7.9(0.02)$ & $0.104(0.004)$ & $2.7(0.01)$ & $1.6(0.003)$ & $0.12(0.0009)$ & $13(0.07)$ & $1.5(0.13)$ \\
\hline Chefe Donsa (Haberu Sefetu) & $7.8(0.05)$ & $0.197(0.01)$ & $1.9(0.01)$ & $1.1(0.004)$ & $0.1(0.001)$ & $11.6(0.1)$ & $1.2(0.09)$ \\
\hline Debre Zeit (Denkaka) & $7.9(0.02)$ & $0.173(0.005)$ & $2.7(0.01)$ & $1.69(0.01)$ & $0.11(0.001)$ & $14.8(0.08)$ & $1.4(0.04)$ \\
\hline Ginichi (Jemjem Legebatu) & $7.8(0.04)$ & $0.224(0.003)$ & $2.3(0.01)$ & $1.34(0.004)$ & $0.11(0.0007)$ & $12.7(0.05)$ & $1.4(0.13)$ \\
\hline Holeta (Guntuta) & $7.8(0.02)$ & $0.11(0.002)$ & $2.3(0.005)$ & $1.32(0.003)$ & $0.11(0.001)$ & $12.5(0.1)$ & $1.9(0.13)$ \\
\hline Mojo (Ajere Wolkite) & $7.2(0.04)$ & $0.125(0.002)$ & $2.8(0.003)$ & $1.65(0.002)$ & $0.12(0.001)$ & $14.3(0.1)$ & $1.7(0.11)$ \\
\hline Sheno (Wentu) & $7.3(0.07)$ & $0.144(0.01)$ & $3.2(0.003)$ & $1.87(0.002)$ & $0.19(0.001)$ & $9.9(0.05)$ & $1.7(0.05)$ \\
\hline Tullu Bolo (Awash Bune) & $7.2(0.03)$ & $0.12(0.005)$ & $1.6(0.01)$ & $0.94(0.004)$ & $0.08(0.0003)$ & $12(0.09)$ & $1.4(0.13)$ \\
\hline Woliso (D/Kora) & $7.8(0.02)$ & $0.201(0.01)$ & $2.1(0.01)$ & $1.21(0.003)$ & $0.11(0.001)$ & $10.7(0.04)$ & $2.1(0.21)$ \\
\hline
\end{tabular}

a Indicates mean

b Indicates standard error in parentheses 
reported by Cottenie [32]. This result is in agreement with the findings of Debele [14]; Mamo et al. [18]; Mamo et al. [20]; Tesgaye [40]; Mamo and Haque [52]; Gebreselassie [53] and Negassa and Gebrekidan [54]. The modest level of annual P application (20-30 $\mathrm{kg} \mathrm{ha}^{-1}$ ) in the form of DAP fertilizer over 15 years was insufficient to raise the soil P levels and satisfy crop requirement.

\section{Available sulfur}

Calcium chloride extractable sulfur (sulfate-S) in the study sites ranged from 1.2 to $2.1 \mathrm{mg} \mathrm{kg}^{-1}$ (Table 4). The available $\mathrm{S}$ contents of samples from all sites were found to be deficient assuming $5 \mathrm{mg} \mathrm{kg}^{-1} \mathrm{~S}$ as critical level (Table 5).

\section{Exchangeable bases and cation exchange capacity}

In neutral Vertisols, the exchangeable sites are occupied mainly by calcium ( $\mathrm{Ca}$ ) and magnesium $(\mathrm{Mg})$ and to a lesser extent by potassium and sodium [43]. Similarly in the present study, the predominant exchangeable cation, which accounts for more than $80 \%$ of the exchange complex was $\mathrm{Ca}^{++}$followed by $\mathrm{Mg}^{++}, \mathrm{K}^{+}$ and $\mathrm{Na}^{+}$. Exchangeable $\mathrm{Ca}$ and $\mathrm{Mg}$ content in the studied soils ranged from 27 to $49 \mathrm{cmol}_{(+)} \mathrm{kg}^{-1}$ and 4.7 to $10 \mathrm{cmol}_{(+)} \mathrm{kg}^{-1}$, respectively (Table 6). According to the rating suggested by Hazelton and Murphy [47], both $\mathrm{Ca}$ and $\mathrm{Mg}$ are in high range at all the sites (Table 5). The exchangeable $\mathrm{K}$ ranged between 1.3 and $2.3 \mathrm{cmol}_{(+)} \mathrm{kg}^{-1}$, which is in a very high range (Tables 5,6 ). Generally, the fairly high level of exchangeable $\mathrm{Ca}, \mathrm{Mg}$ and $\mathrm{K}$ is consistent with the findings of earlier studies [38, 39, 45].

It has been suggested that the proportions of the basic cations of the effective cation exchange capacity are more relevant to plant performance than the actual levels [47]. According to Abbott [60], the potassium saturation

Table 5 Critical levels of macro and micronutrients with different soil tests as reported by different authors

\begin{tabular}{llll}
\hline Elements & Method used & Critical levels & References \\
\hline $\mathrm{P}$ & Olsen & $10-17 \mathrm{mg} \mathrm{kg}^{-1}$ & {$[32]$} \\
$\mathrm{K}$ & $\mathrm{NH}_{4} \mathrm{OAc}, \mathrm{pH}=7$ & $0.3-0.7 \mathrm{cmol} \mathrm{kg}^{-1}$ & {$[47]$} \\
$\mathrm{Ca}$ & $\mathrm{NH}_{4} \mathrm{OAC}, \mathrm{pH}=7$ & $5-10 \mathrm{cmol} \mathrm{kg}^{-1}$ & {$[47]$} \\
$\mathrm{Mg}$ & $\mathrm{NH}_{4} \mathrm{OAc}, \mathrm{pH}=7$ & $1-3 \mathrm{cmol} \mathrm{kg}^{-1}$ & {$[47]$} \\
Sulfate-S & $\mathrm{CaCl}_{2}$ & $5 \mathrm{mg} \mathrm{kg}^{-1}$ & {$[55]$} \\
$\mathrm{Cu}$ & $\mathrm{AB}-\mathrm{DTPA}$ & $0.5 \mathrm{mg} \mathrm{kg}^{-1}$ & {$[56,57]$} \\
$\mathrm{Fe}$ & $\mathrm{AB}-\mathrm{DTPA}$ & $5 \mathrm{mg} \mathrm{kg}^{-1}$ & {$[56,57]$} \\
$\mathrm{Mn}$ & $\mathrm{AB}-\mathrm{DTPA}$ & $1 \mathrm{mg} \mathrm{kg}^{-1}$ & {$[56,57]$} \\
$\mathrm{Zn}$ & $\mathrm{AB}-\mathrm{DTPA}$ & $1.5 \mathrm{mg} \mathrm{kg}^{-1}$ & {$[56,57]$} \\
$\mathrm{Mo}$ & $\mathrm{AAO}$ & $0.1-0.5 \mathrm{mg} \mathrm{kg}^{-1}$ & {$[35,58]$} \\
$\mathrm{B}$ & Mehlich 3 & $0.5-1 \mathrm{mg} \mathrm{kg}^{-1}$ & {$[58,59]$} \\
\hline
\end{tabular}

percentage (3.2-5.4\%) of the studied soils was found to be desirable proportion for many plants (Table 6). Nevertheless, antagonistic effects could exist when disproportionate quantities of exchangeable cations are present in the soil. Potassium to magnesium ratio of the studied soils varied from $0.17: 1$ to $0.44: 1$ (Table 6), which indicated $\mathrm{Mg}$-induced $\mathrm{K}$ deficiency using the rating of Loide [61]. This can be corrected by $\mathrm{K}$ application to bring the $\mathrm{K}$ to $\mathrm{Mg}$ ratio closer to $0.7: 1$. The low $\mathrm{K}$ to $\mathrm{Mg}$ ratios may result in $\mathrm{K}$ adsorption to cation exchange sites, which reduce $\mathrm{K}$ activity in the soil [62]. Many soils with vermiculitic or micaceous components of the clay fraction have a preferential adsorption of $\mathrm{K}^{+}$over $\mathrm{Ca}^{2+}$ or $\mathrm{Mg}^{2+}$ $[63,64]$. If there is a high preferential $K$ adsorption on the exchange sites of clay minerals, the amount of $\mathrm{K}$ desorbing may then decline, resulting in a reduced $K$ uptake at low soil exchangeable $\mathrm{K}$ to $\mathrm{Mg}$ ratio. Therefore, attempts should be made to supply the plants with potassium in physiologically correct ratio and in a sustainable manner.

Vertisols usually have a relatively high CEC, which ranges between 20 and $45 \mathrm{cmol}_{(+)} \mathrm{kg}^{-1}$ soil and even more [65]. In Ethiopia, Debele [14] reported that nearly all the Vertisols have high CEC of $35-70 \mathrm{cmol}_{(+)} \mathrm{kg}^{-1}$. According to the rating of Hazelton and Murphy [47], CEC of the studied soils were very high and ranged between 37 and $58 \mathrm{cmol}_{(+)} \mathrm{kg}^{-1}$ (Table 6). The very high value of $C E C$ is mainly due to high clay content and predominance of 2:1 layer clay minerals.

\section{Micronutrients}

The AB-DTPA extractable $\mathrm{Cu}$ ranged from 2.9 to $6 \mathrm{mg} \mathrm{kg}^{-1}$ in the surface soils (Additional file 3: Figure $\mathrm{S} 3) . \mathrm{Cu}$ was found adequate in all the samples as compared with the values of Soltanpour [56] and Jones [57] (Table 5). The result was similar to that of Abera and Kebede [66], who reported that $\mathrm{Cu}$ concentration is at an adequate level in the central highlands of Ethiopia. This was further supported by EthioSIS finding. The AB-DTPA extractable Fe varied from 22 to $77 \mathrm{mg} \mathrm{kg}^{-1}$ (Additional file 3: Figure S3). In this study, considering $5 \mathrm{mg} \mathrm{kg}^{-1}$ AB-DTPA extractable Fe as critical, samples from all sites were found to have sufficient level of available Fe (Table 5). The result was similar to the finding of Itanna [67] who reported adequate content of soil Fe in Ethiopian Vertisols. However, deficiency of Fe was recorded by Abera and Kebede [66] in central highland Vertisols of Ethiopia. The finding of EthioSIS has also indicated that iron deficiency existed in soils of four major regions (Tigray, Amhara, Oromia and Southern), but it was more prevalent (41\%) in Tigray agricultural soils.

The AB-DTPA extractable $M n$ ranged from 22 to $100 \mathrm{mg} \mathrm{kg}^{-1}$ (Additional file 3: Figure S3). Based on the 
Table 6 Exchangeable bases, cation exchange capacity (CEC), K saturation percentage, $\mathrm{K}$ to $\mathrm{Mg}$ ratio, available molybdenum (Mo) and boron (B) content of the study sites $(n=12)$

\begin{tabular}{|c|c|c|c|c|c|c|c|c|c|}
\hline \multirow[t]{2}{*}{ Location (District) } & \multicolumn{4}{|c|}{ Exchangeable bases $\left(\mathrm{cmol}_{(+)} \mathbf{k g}^{-1}\right)$} & \multirow{2}{*}{$\begin{array}{l}\text { CEC } \\
\left(\mathrm{cmol}(+) \mathrm{kg}^{-1}\right)\end{array}$} & \multirow{2}{*}{$\begin{array}{l}\mathrm{K} / \mathrm{CEC} \\
(\%)\end{array}$} & \multirow[t]{2}{*}{$\mathrm{K}: \mathrm{Mg}$} & \multirow{2}{*}{$\begin{array}{l}\text { AAO }\left(\mathrm{mg} \mathrm{kg}^{-1}\right) \\
\text { Mo }\end{array}$} & \multirow[t]{2}{*}{ Mehlich3 $\left(\mathrm{mg} \mathrm{kg}^{-1}\right) \mathrm{B}$} \\
\hline & $\mathrm{Ca}$ & $\mathrm{Mg}$ & K & $\mathrm{Na}$ & & & & & \\
\hline Akaki (Akaki) & $38^{\mathrm{a}}(0.17)^{\mathrm{b}}$ & $9.4(0.03)$ & $1.6(0.002)$ & $0.16(0.002)$ & $49.4(0.16)$ & 3.2 & $0.17: 1$ & $0.003(0.002)$ & $<0.5$ \\
\hline Ambo (Kisole Odoliva) & $45.2(0.08)$ & $7(0.02)$ & $1.8(0.008)$ & $0.1(0.003)$ & $54.6(0.09)$ & 3.3 & $0.26: 1$ & $0.01(0.01)$ & $<0.5$ \\
\hline $\begin{array}{l}\text { Chefe Donsa (Haberu } \\
\text { Sefetu) }\end{array}$ & $32.8(0.2)$ & $5.2(0.5)$ & $1.8(0.16)$ & $0.27(0.006)$ & $42.1(0.15)$ & 4.3 & $0.35: 1$ & $0.005(0.002)$ & $<0.5$ \\
\hline Debre Zeit (Denkaka) & $49(0.11)$ & $5.2(0.01)$ & $2.3(0.01)$ & $0.07(0.002)$ & $56.5(0.13)$ & 4.1 & $0.44: 1$ & $0.02(0.01)$ & $<0.5$ \\
\hline Ginichi (Jemjem Legebatu) & ) $48.8(0.04)$ & $6.7(0.03)$ & $1.9(0.008)$ & $0.17(0.004)$ & $58(0.03)$ & 3.3 & $0.28: 1$ & $0.01(0.01)$ & $<0.5$ \\
\hline Holeta (Guntuta) & $34.1(0.1)$ & $8(0.04)$ & $1.5(0.02)$ & $0.18(0.003)$ & $44.3(0.16)$ & 3.4 & $0.19: 1$ & $0.01(0.005)$ & $<0.5$ \\
\hline Mojo (Ajere Wolkite) & $32.4(0.17)$ & $9.8(0.12)$ & $1.9(0.007)$ & $0.13(0.003)$ & $44.5(0.23)$ & 4.3 & $0.19: 1$ & $0.01(0.005)$ & $<0.5$ \\
\hline Sheno (Wentu) & $28.3(0.11)$ & $9.7(0.03)$ & $1.3(0.008)$ & $0.11(0.005)$ & $39.8(0.15)$ & 3.3 & $0.13: 1$ & $0.02(0.008)$ & $<0.5$ \\
\hline Tullu Bolo (Awash Bune) & $27.1(0.2)$ & $8.8(0.07)$ & $2.1(0.02)$ & $0.41(0.002)$ & $38.8(0.3)$ & 5.4 & $0.24: 1$ & $0.01(0.003)$ & $<0.5$ \\
\hline Woliso (D/Kora) & $30.8(0.08)$ & $4.7(0.02)$ & $1.8(0.002)$ & $0.08(0.005)$ & $37.8(0.11)$ & 4.8 & $0.38: 1$ & $0.01(0.003)$ & $<0.5$ \\
\hline
\end{tabular}

a Indicates mean

b Indicates standard error in parentheses

critical value given by Soltanpour [56] and Jones [57], samples from all sites were found to have sufficient level of available Mn (Table 5). The sufficient levels of Mn in all the sites were consistent with findings of Itanna [67] who reported adequate content of soil Mn in Ethiopian Vertisols. Likewise, EthioSIS reported sufficient Mn levels in different soil types of Ethiopia including Vertisols. Nevertheless, a deficient level of Mn was recorded by Abera and Kebede [66] in central highland Vertisols of Ethiopia.

Zinc has low mobility in soils and tendency of being adsorbed on clay particles [68]. As shown in Additional file 3: Figure S3, AB-DTPA extractable $\mathrm{Zn}$ in the surface soils $(0-15 \mathrm{~cm})$ ranged from 1.1 to $2.7 \mathrm{mg} \mathrm{kg}^{-1}$. However, the values recorded were lower than the critical level of $1.5 \mathrm{mg} \mathrm{kg}^{-1}$ as established by Soltanpour [56] and Jones [57] except in Ambo, Holeta and Sheno (Table 5). In confirmation with this study, Asegelil et al. [69] reported Zn deficiency in $78.4 \%$ of the soil samples collected from Vertisols of Ethiopia. This was further supported by Abera and Kebede [66] who reported deficiency of $\mathrm{Zn}$ in $98 \%$ of the soil samples collected from central highland Vertisols of Ethiopia. A recent finding by Bereket et al. [70] also supported Zn deficiency on Ethiopian Vertisols. Similarly, this was reported by the findings of EthioSIS. The inherently low content of zinc in these soils may have been further depleted by intensive cropping. The poor availability of $\mathrm{Zn}$ in $70 \%$ of the sites needs immediate intervention to improve wheat production.

Results reported by different researchers [59, 71-73] indicate that Mehlich 3 extracts comparable amounts of $\mathrm{B}$ as the hot water-soluble method. Consequently, we have used the sufficiency range $\left(0.5-1 \mathrm{mg} \mathrm{kg}^{-1}\right)$ of $B$ extracted using hot water-soluble method and applied it to Mehlich 3 extractable B. Samples from all sites in the study were found to be deficient (Tables 5, 6). Comparison of the acid ammonium oxalate extractable Mo with the sufficiency range of $0.1-0.3 \mathrm{mg} \mathrm{kg}^{-1}[35,58]$ showed that samples from all sites were also found to be deficient (Tables 5, 6).

\section{Wheat nutrient status}

Data on wheat flag leaves analysis at flowering stage showed that $\mathrm{N}$ content varied from 1.4 to $2 \%$ (Additional file 2: Figure S2). Tissue $\mathrm{N}$ concentration of samples from all sites was below the critical value of $3.6 \%$, suggesting there were insufficient $\mathrm{N}$ levels in the plant [74] (Table 7). To increase the pool of $\mathrm{N}$ available for crop growing, agricultural activities should focus on proper $\mathrm{N}$ management via application of $\mathrm{N}$ fertilizers and organic amendments and cultivation of wheat after legumes.

Table 7 Sufficiency ranges for nutrient content in wheat (flag leaves at flowering stage)

\begin{tabular}{lll}
\hline Nutrients & Sufficiency range & References \\
\hline $\mathrm{N}(\%)$ & $3.6-4.5$ & {$[74]$} \\
$\mathrm{P}(\%)$ & $0.2-0.5$ & {$[76]$} \\
$\mathrm{K}(\%)$ & $1.5-3$ & {$[77]$} \\
$\mathrm{Ca}(\%)$ & $0.2-1$ & {$[76]$} \\
$\mathrm{Mg}(\%)$ & $0.15-0.5$ & {$[77]$} \\
$\mathrm{Cu}\left(\mathrm{mg} \mathrm{kg}^{-1}\right)$ & $4.5-15$ & {$[76]$} \\
$\mathrm{Fe}\left(\mathrm{mg} \mathrm{kg}^{-1}\right)$ & $30-200$ & {$[76]$} \\
$\mathrm{Mn}\left(\mathrm{mg} \mathrm{kg}^{-1}\right)$ & $20-150$ & {$[76]$} \\
$\mathrm{Zn}\left(\mathrm{mg} \mathrm{kg}^{-1}\right)$ & $18-70$ & {$[76]$} \\
\hline
\end{tabular}


As a consequence, the pool of $\mathrm{N}$ potentially available for the crop increases, which should improve the $\mathrm{N}$ status and yield of crops [75]. Phosphorus concentration in wheat leaves ranged from 0.05 to $0.15 \%$ at flowering stage (Additional file 2: Figure S2). According to Plank and Donohue [76], $\mathrm{P}$ was deficient in samples from all sites but the values were close to the lower limit of sufficiency range at three sites (Mojo, Sheno and Tullu Bolo) (Table 7). Similarly, K ranged from 0.8 to $1.4 \%$ and was found to be deficient in samples from all sites (Additional file 2: Figure S2). About $70 \%$ of the tissue K content of the flag leaves was slightly under the lower limit of the sufficiency range suggested by Jones [77]. The deficient tissue $\mathrm{K}$ content was not predicted by the soil exchangeable K test. Similarly, response to K has been observed on Ethiopian Vertisols with high amount of ammonium acetate extractable K [78]. This was further supported by the findings of Suba and Srivastava [79], who reported that Vertisols with high exchangeable and non-exchangeable $\mathrm{K}$ showed a response to applied $\mathrm{K}$, though the response was different depending on the type of plant. The poor agreement between the soil $\mathrm{K}$ status and response to $\mathrm{K}$ fertilizer is due to the fact that $\mathrm{K}$ response is affected by other soil variables like $\mathrm{K}$ saturation to cation exchange capacity, the proportion of $\mathrm{K}$ to other basic cations and $\mathrm{K}$ fixation capacity of clay minerals. In this regard, the $\mathrm{K}$ recommendations which depend on the cation exchange capacity and/or clay content of the soil have been compiled [80, 81]. For example, in India, Suba and Srivastava [79] have quadrupled K critical level for smectite-rich swell and shrink soils. Moreover, EthioSIS has established a critical value of Mehlich 3 extractable K of $190 \mathrm{mg} \mathrm{kg}^{-1}$ based on field crop $\mathrm{K}$ response and soil analysis results, suggesting the need to amend the threshold value of $K$ to get a common and realistic recommendation for $\mathrm{K}$ across all Vertisols of Ethiopia for sustainable crop production. Calcium and magnesium content of the wheat leaves ranged from 0.3 to $0.5 \%$ and 0.25 to $0.83 \%$, respectively (Additional file 2: Figure S2). Both $\mathrm{Ca}$ and $\mathrm{Mg}$ were found to be within the sufficiency range made in Plank and Donohue [58] and Jones et al. [74], respectively (Table 7).

Regarding wheat micronutrient tissue concentrations, $\mathrm{Cu}$ concentration in wheat leaves ranged from 6.1 to $9.6 \mathrm{mg} \mathrm{kg}^{-1}$, Fe from 71 to $97 \mathrm{mg} \mathrm{kg}^{-1}$, Zn from 7.5 to $18 \mathrm{mg} \mathrm{kg}^{-1}$, Mn from 29 to $100 \mathrm{mg} \mathrm{kg}^{-1}$ and $\mathrm{Cl}$ from 0.54 to $1.3 \mathrm{mg} \mathrm{kg}^{-1}$ (Additional file 3: Figure S3). All the plant samples were sufficient in $\mathrm{Cu}, \mathrm{Fe}$ and $\mathrm{Mn}$ as given in Plank and Donohue [76] and Jones et al. [77] (Table 7). Since the contents of $\mathrm{Fe}$ and $\mathrm{Mn}$ in all the samples were far above the critical levels, their deficiency may not be expected in the foreseeable future as far as wheat crop is concerned. Zinc status of bread wheat flag leaf at flowering stage was deficient according to the sufficiency range in Plank and
Donohue [76] which agreed with the low levels of $\mathrm{Zn}$ in the soil (Table 7). Tissue $\mathrm{Cl}$ concentration of all the samples was above the critical value of $0.4 \%$ [82], suggesting there were sufficient $\mathrm{Cl}$ in the soils (Table 8 ).

\section{Soil and wheat nutrient content relationships}

Interpretation of soil test results and plant analysis data is essential for further development of nutrient management. Additional files 2 (Figure S2) and 3 (Figure S3) presented the interrelation between soil and wheat flag leaf nutrient contents at flowering stage, collected from ten Vertisols of central highlands of Ethiopia. Soil and tissue nutrient concentrations were expected to be positively correlated for most nutrients because the concentration of a particular nutrient in the plant is generally greater when the concentration in the soil is greater [51]. Soil total N and $\mathrm{C}: \mathrm{N}$ ratio had no significant correlation (unrelated) with plant $\mathrm{N}$ content at flowering stage. However, soil $\mathrm{P}, \mathrm{K}, \mathrm{Ca}, \mathrm{Mg}, \mathrm{Cu}, \mathrm{Fe}, \mathrm{Mn}$ and $\mathrm{Zn}$ concentrations exhibited a significant positive correlation with tissue nutrient concentrations. This indicated that soil total $\mathrm{N}$ did not proportionally alter internal plant $\mathrm{N}$ content, and it was less affected by changes in soil total $\mathrm{N}$ concentration than other nutrients. The mobility of $\mathrm{N}$ in the soil makes it difficult to get a solid representation of the available $\mathrm{N}$ concentration in soils. The highest correlation $(r>0.90)$ between soil and plant nutrient content was observed for $\mathrm{P}, \mathrm{K}, \mathrm{Mg}, \mathrm{Cu}, \mathrm{Fe}, \mathrm{Mn}$ and $\mathrm{Zn}$ (Additional file 2: Figure S2, Additional file 3: Figure S3), implying that flag leaves at flowering stage can be used to calibrate soil and plant contents for the deficient nutrients.

\section{Conclusions}

From the present study, it can be concluded that the soil analysis data of wheat fields in central highland Vertisols

Table 8 Chloride content of wheat leaf samples from ten wheat growing areas of central highland Vertisols $(n=6)$

\begin{tabular}{lc}
\hline Location (District) & Cl (\%) \\
\hline Akaki (Akaki) & $1^{\mathrm{a}}(0.04)^{\mathrm{b}}$ \\
Ambo (Kisole Odoliva) & $1.1(0.03)$ \\
Chefe Donsa (Haberu Sefetu) & $1.1(0.05)$ \\
Debre Zeit (Denkaka) & $1(0.05)$ \\
Ginichi (Jemjem Legebatu) & $1.2(0.03)$ \\
Holeta (Guntuta) & $1.2(0.1)$ \\
Mojo (Ajere Wolkite) & $1.3(0.1)$ \\
Sheno (Wentu) & $0.94(0.06)$ \\
Tullu Bolo (Awash Bune) & $0.84(0.01)$ \\
Woliso (D/Kora) & $0.54(0.01)$
\end{tabular}

a Indicates mean

b Standard error in parentheses 
of Ethiopia showed deficiency in the levels of N, P, S, Zn, Mo and B. Moreover, the plant analysis data from the same sites indicated that wheat plants were deficient in $\mathrm{N}, \mathrm{P}, \mathrm{Zn}$ and $\mathrm{K}$. The nutrient deficiencies identified in this study could be due to either inherently low availability of these nutrients in the soils or as a consequence of continuous intensive cropping without applying fertilizer or manure containing these nutrients. The results of this study show the need for further studies in the deficient areas for determining wheat response to balanced fertilization. Further research on a wide range of wheat growing Ethiopian highland Vertisols is desirable to obtain holistic view of wheat nutrition. The rallies and training programmes for the farmers should be arranged for increasing awareness regarding the benefits of inorganic fertilizers other than DAP and urea in improving soil fertility, nutrient status and crop production.

\section{Additional files}

Additional file 1: Figure S1. Geographical map of the sampling sites. Additional file 2: Figure S2. Literature critical levels and plant vs. soil macro-nutrient contents of the study sites.

Additional file 3: Figure S3. Literature critical levels and plant vs. soil micro-nutrient contents of the study sites.

\section{Abbreviations}

$\mathrm{NH}_{4} \mathrm{OAc}$ : ammonium acetate; $\mathrm{AB}-\mathrm{DTPA}$ : ammonium bicarbonate di-ethylene tri-amine penta-acetic acid; AAO: acidic ammonium oxalate; CEC: cation exchange capacity; DAP: di-ammonium phosphate; EDTA: ethylene diamine tetra-acetic acid; EC: electrical conductivity; EthioSIS: Ethiopian soil information system; FAO: food and agriculture organization; GPS: global positioning system; ICP-OES: inductively coupled plasma-optical emission spectrometer; SOM: soil organic matter; TC: total carbon; TN: total nitrogen.

\section{Authors' contributions}

$\mathrm{HH}$ and TM conceived the study. All authors participated in the design and coordination. $\mathrm{HH}$ collected and analyzed the samples and interpreted the data, which was part of her Doctorial thesis of Soil Science at Haramaya University, Ethiopia. All the authors also helped to draft the manuscript as well as approved the final manuscript. All authors read and approved the final manuscript.

\section{Authors'information}

$\mathrm{HH}$ is a doctorial candidate in the department of Soil Science, College of Agriculture and Environmental Sciences, Haramaya University, Haramaya, Ethiopia. She is a lecturer in college of Natural and Computational sciences at Wollo University, Wollo, Ethiopia. TM is a professor of Soil Science, Minster's Advisor/State Minster at Ethiopian Ministry of Agriculture. TM received his PhD degree in soil chemistry and fertility from Aberdeen University, Scotland. RK is a senior researcher of soil and plant nutrition at Natural Resources Institute Finland (Luke), Jokioinen, Finland. RK obtained her PhD degree in Agriculture and Forestry from Helsinki University, Finland. EK is an associate professor in Soil Science and an international consultant in soil fertility mapping and fertilizer recommendations at Ethiopian Agricultural Transformation Agency (ATA). EK received his PhD degree in Soil Science from Swedish University of Agricultural Sciences. HG is a professor of Soil Science at Haramaya University, Haramaya, Ethiopia. HG obtained his PhD degree in Soil and Water Science from University of Arizona, Tucson, Arizona. TB is a senior researcher of soil science at ATA, Addis Ababa, Ethiopia. TB obtained his PhD degree in Soil Science from Justus-Liebig University, Giessen, Germany.

\section{Author details}

${ }^{1}$ College of Natural and Computational Sciences, Wollo University, Dessie, Ethiopia. ${ }^{2}$ Ministry of Agriculture, Addis Ababa, Ethiopia. ${ }^{3}$ Natural Resources Institute Finland (Luke), 31600 Jokioinen, Finland. ${ }^{4}$ Department of Soil and Environment, Swedish University of Agricultural Sciences, Uppsala, Sweden. ${ }^{5}$ College of Agriculture and Environmental Sciences, Haramaya University, Haramaya, Ethiopia. ${ }^{6}$ Agricultural Transformation Agency, Addis Ababa, Ethiopia.

\section{Acknowledgements}

The authors gratefully acknowledge the International Potash Institute and Ethiopian Ministry of Education for funding the study. Deep appreciation is expressed to the Debre Zeit Agricultural Research Center, Ethiopia and Natural Resources Institute, Finland for the provision of laboratory facilities. Sincere collaboration of the technical assistants during the laboratory analyses is greatly acknowledged. We would like to thank Samuel Feyissa for the map of the study area. We are also grateful to all farmers and development agents who participated in the study.

\section{Competing interests}

The authors declare that they have no competing interests.

Received: 12 April 2015 Accepted: 13 October 2015

Published online: 01 December 2015

\section{References}

1. Amsalu A, Stroosnijder L, Graaf G. Long-term dynamics in land resource use and the driving forces in the Beressa watershed, highlands of Ethiopia. J Environ Manage. 2007;83:448-59.

2. Tsegaye G, Bekele W. Farmers' perceptions of land degradation and determinants of food security at Bilate watershed, Southern Ethiopia. Ethio J Appl Sci Technol. 2010;1:49-62.

3. Zeleke G, Hurni H. Implications of land use and land cover dynamics for mountain resource degradation in the Northwestern Ethiopian highlands. Mt Res Dev. 2000;22:184-91.

4. Matson PA, Naylor R, Ortiz-Monasterio I. Integration of environmental, agronomic, and economic aspects of fertilizer management. Sci. 1998;280:112-5.

5. Lakew D, Carrucci V, Asrat W, Yitayew A. Community based participatory watershed development: a Guide line Ministry of agriculture and Rural Development Addis Ababa, Ethiopia. 2005. http://agriwaterpedia.info/ images/f/fe/MinistryAgricultureEthiopiaCommunityBasedWatershedManagementGuideline2005Part1A.pdf. Accessed 3 Dec 2014.

6. Smaling EM, Nandwa SM, Janssen BH. Soil fertility in Africa is at stake. In: Buresh RJ, Sanchez PA, Calhoom F, editors. Replenishing soil fertility in Africa. Sol Sci Soc Am 1997. Vol 51. p. 47-61.

7. $F A O$ (Food and Agriculture Organization). Soil fertility management in support of food security in Sub-Saharan Africa. Rome, Italy. 2001. ftp://fao. org/agl/agll/docs/foodsec.pdf. Accessed 20 Jan 2015.

8. Sanchez PA. Soil fertility and hunger in Africa. Sci. 2002;295:2010-9.

9. Haileselassie A, Priess JA, Veldkamp E, Teketay D, Lesschen JP. Assessment of soil nutrient depletion and its spatial variability on smallholders' mixed farming systems in Ethiopia using partial versus full nutrient balances. Agric Ecosyst Environ. 2005;108:1-16.

10. Asfaw B, Heluf G, Yohannes U, Eylachew Z. Effect of crop residues on grain yield of sorghum (Sorghum bicolor) to application of $\mathrm{N}$ and P Fertilizers. Nutr Cycl Agecosys. 1997:48:191-6.

11. Abebe M. Nature and management of Ethiopian soils. East Hararge, Ethiopia: Alemaya University of Agriculture; 1998. p. 272.

12. Endale K. Fertilizer consumption and agricultural productivity in Ethiopia. Ethiopian Development Research Institute working paper 003. 2011. p. 7.

13. Jutzi SC, Assamnew G, Haque I, Tedla A, Astatike A. Intermediate technology for increased food and feed production from deep black clay soils in the Ethiopian highlands. In: Proceedings of FAO/SIDA seminar on increased food production through low cost food crop technology. Harare, Zimbabwe. 1987. p. 373-83.

14. Debele B. The Vertisols of Ethiopia: their properties, classification and management. In: Fifth Meeting of the Eastern African Sub-Committee for 
Soil Correlation and Land Evaluation, 5-10 December 1983 Wad Medani, Sudan. World Soil Resources Reports No. 56. FAO (Food and Agriculture Organization), Rome. 1985. p. 31-54.

15. Debele B. Management of Vertisols and catchments treatment on Delanta Dawunt plateau, North Wollo prepared for Oxfam-GB Addis Ababa, May, 2000.

16. Beyene $\mathrm{D}$. The response of pulse crops to $\mathrm{N}$ and $\mathrm{P}$ fertilizers. In: Beyene $\mathrm{D}$, editor. Workshop on review of soil science research in Ethiopia. Addis Ababa, Ethiopia, 11-14 February 1986. IAR (Institute of Agricultural Research), Addis Ababa, Ethiopia. 1986; p. 87-91.

17. Rutherford AS. Broad bed maker technology package innovations in Ethiopian farming systems: an ex-post impact assessment. Research report 20. ILRI (International Livestock Research Institute), Nairobi, Kenya. 2008. p. 6-10

18. Mamo T, Haque I, Kamara CS. Phosphorus status of some Ethiopian highland Vertisols. In: Management of Vertisols in sub-Saharan Africa. Proceedings of a conference held at International Livestock Centre for Africa (ILCA), 31 August-4 September 1987 Addis Ababa, Ethiopia. 1988. p. 232-52.

19. Mamo T, Richter C, Heiligtag B. Phosphorus availability studies on ten Ethiopian Vertisols. JARTS. 2002;103:177-83.

20. EthioSIS (Ethiopian Soil Information System). 2015. http://www.ata.gov. et/highlighted-deliverables/ethiopian-soil-information-system-ethiosis/. Accessed 15 March 2015.

21. Abunyewa A, Asiedu EK, Ahenkorah Y. Fertilizer phosphorus fractions and their availability to maize on different land forms on a Vertisol in the coastal Savana zone of Ghana. West African J Appl Ecol. 2004;5:63-73.

22. Gary WH. A futuristic view of soil and plant analysis and nutrient recommendations. Commun Soil Sci Plant Anal. 1998;29:11-4.

23. Jutzi SC, Abebe M. Improved agricultural utilization of Vertisols in the Ethiopian highlands an interinstitutional approach. In: Latham M, Ahn P, Elliott CR, editors. Management of Vertisols under Semi-Arid Conditions. Proceeding of the first Regional Seminar. IBSRAM, Bangkok. 1987. p. 173-83.

24. Andreas P, Berndt-Micheal W. Soil sampling and storage. In: Margesin R, Schinner F, editors. Manual for soil analysis monitoring and assessing soil bioremediation. Springer-Verlag: Berlin Heidelberg; 2005. p. 3-13.

25. Gee GW, Bauder JW. Particle Size Analysis. In: Klute A, editor. Methods of Soil Analysis. American Society of Agronomy. 1986. Vol 7, p. 383-411.

26. Rhoades JD. In: Miller RH, Keeney DR, editors. Methods of soil analysis. American Society of Agronomy. 1982. p. 539-79.

27. Black CA. Methods of soil analysis. American Society of Agronomy; 1965

28. ISO (International Organization for Standardization) 10694. Soil qualityDetermination of organic and total carbon after dry combustion (elemental analysis). 1995

29. ISO (International Organization for Standardization) 13878. Soil qualityDetermination of total nitrogen content by dry combustion (elemental analysis). 1998.

30. Olsen SR, Cole CV, Wanatabe FS, Dean LA. Estimation of available phosphorus in soils by extraction with sodium bicarbonate. 1954. USDA Circular, p. 939

31. Williams $\mathrm{CH}$, Steinbergs A. Soil sulfur fractionations as chemical indices of available sulfur in some Australian soils. Aust J Agri Res. 1959;10:340-52.

32. Cottenie A. Soil and plant testing as a basis of fertilizer recommendations. FAO soil bulletin 38/2. Food and Agriculture Organization of the United Nations, Rome, Italy. 1980.

33. Soltanpour PN, Schwab AP. A new soil test for simultaneous extraction of macro and micro-nutrients in alkaline soils. Commun Soil Sci Plant Anal. 1977;8:195-207.

34. Mehlich A. Mehlich 3 Soil test extractant: a modification of the Mehlich 2 extractant. Commun Soil Sci Plant Anal. 1984;15:1409-16.

35. Grigg JL. Determination of the available molybdenum of soils. J Sci Tech N Zealand. 1953;30:405-14.

36. Bremner JM, Mulvaney CS. Total nitrogen. In: Page AL, Miller RH, editors. Methods of soil analysis. American Society of Agronomy. 1982. p. 595-624.

37. Jones JB Jr. Laboratory guide for conducting soil tests and plant analysis. 2001. p. 227.

38. Kamara CS, Haque I, Beyene D. Characteristics of soils at the IAR research sub-centres at Sheno and Ginchi. Addis Ababa: ILCA; 1989. p. 55.
39. Lemma G, Smit GN. Relationships between plant and soil nutrient status and position in the landscape on Pellic Vertisols of Ethiopia. S Afr J Plant Soil. 2008;25:119-26.

40. Tsegaye T. Vertisols of central highlands of Ethiopia: Characterization and evaluation of the phosphorus status. MSc Thesis Submitted to the School of Graduate Studies, Alemaya University of Agriculture, East Hararge, Ethiopia. 1992.

41. Murphy HF. A report on fertility status and other data on some soils of Ethiopia. Experimental Station Bulletin No. 44, Collage of Agriculture HSIU. 1968. p. 551.

42. Taddese T. Soil, plant, water, fertilizer, animal manure and compost analysis. Working Document No. 13. International Livestock Research Center for Africa, Addis Ababa, Ethiopia. 1991.

43. Kebede F, Charles Y. Soil fertility status and Numass fertilizer recommendation of Typic Hapluustertes in the northern highlands of Ethiopia. World Appl Sci J. 2009;6:1473-80.

44. FAO. Fertilizers and their use. 4th ed. Rome: International Fertilizer Industry Association, FAO; 2000. p. 9-11.

45. Beyene D. Diagnosis of phosphorus deficiency in Ethiopian soils. In: Soil Science Bulletin No.3. IAR (Institute of Agriculture), Addis Ababa, Ethiopia. 1982. p. 1-23.

46. Esayas A. Some physico-chemical characteristics of the Raya valley report. Ethio J Natural Resor. 2001;3:179-93.

47. Hazelton P, Murphy B. Interpreting soil test results: What do all the numbers mean? 2nd ed. CSIRO; 2007

48. Landon JR. Booker tropical soil manual: A hand book for soil survey and agricultural land evaluation in the tropics and subtropics. Essex: Longman scientific and technical; 1991.

49. Beyene D. Soil fertility research on some Ethiopian Vertisols. In: Management of Vertisols in sub-Saharan Africa Proceedings of a conference held at ILCA. 31 August-4 September 1987. ILCA (International Livestock Centre for Africa), Addis Ababa, Ethiopia. 1988. p. 223-31.

50. Finck $A$, Venkateswarlu J. Chemical properties and management of Vertisols. In: Vertisols and rice soils of the tropics. 12th International Congress of Soil Science, New Delhi, India, Indian Society of Soil Science, New Delhi, India. 1982. p. 61-9.

51. Mengel K, Kirkby EA. Principles of plant nutrition. Panima Publ. Corporation, New Delhi, Bangalore, India. 1987. p. 6-103 (687).

52. Mamo T, Haque I. Phosphorus status of some Ethiopian soils, II. Forms and distribution of inorganic phosphates and their relation to available phosphorus. Trop Agric. 1991;68:2-8.

53. Gebreselassie Y. Selected chemical and physical characteristics of soils of Adet Resaerch Centre and its testing sites in northwestern Ethiopia. EJNR. 2002;4:199-215.

54. Negassa W, Gebrekidan H. Forms of phosphorus and status of available micronutrients under different land-use systems of Alfisols in Bako area of Ethiopia. EJNR. 2003;5:17-37.

55. Lewis DC. Sulfur. In: Peverill KI, Sparrow LA, Reuter DJ, editors. Soil analysis an interpretation manual. Collingwood: CSIRO Publishing; 1999. p. 221-8.

56. Soltanpour PN. Use of AB-DTPA soil test to evaluate elemental availability and toxicity. Commun Soil Sci Plant Anal. 1985;16:323-38.

57. Jones JB. Agronomic Handbook: Management of crops, soils, and their Fertility. Boca Raton: CRC Press LLC; 2003. p. 482.

58. Sims JT, Johnson CV. Micronutrient soil tests. In: Mortvedt JJ, Cox FR, Shuman LM, Welch RM, editors. Micronutrients in Agriculture. Book series No. 4. Madison: Soil Science Society of America; 1991. p. 427-76.

59. Shuman LM, Bandel VA, Donohue SJ, Isaac RA, Lippert RM, Sims JT, Tucker MR, et al. Comparison of Mehlich-1 and Mehlich-3 extractable soil boron with hot water extractable boron. Commun Soil Sci Plant Anal. 1992;23:1-14.

60. Abbott TS. BCRI soil testing methods and interpretation. Rydalmere: Biological and Chemical Research Institute, NSW Agriculture and Fisheries; 1989

61. Loide V. About the effect of the contents and ratios of soil's available calcium, potassium and magnesium in liming of acid soils. Agron Res. 2004;2:71-82.

62. Dobermann A, Cassman KG, Sta PC, Cruz MA, Adviento, Pampolino MF, et al. Fertilizer inputs, nutrient balance, and soil nutrient-supplying power in intensive, irrigated rice systems. II: Effective soil K-supplying capacity. Nutri Cycl Agroecosyst. 1996;46:11-21. 
63. Parfitt RL. Potassium-calcium exchange in some New Zealand soils. Aust J Soil Res. 1992;30:145-58.

64. Rhue RD, Mansell RS. The effect of pH on sodium calcium and potassium-calcium exchange selectivity for Cecil soil. Soil Sci Soc Am J. 1988;52:641-7.

65. Ahmed N, Mermut A. Vertisols and technologies for their management. Developments in Soil Science 24. Elsevier Science, Amsterdam, the Netherlands. 1996.

66. Abera Y, Kebede M. Assessment on the status of some micro nutrients in Vertisols of central highlands of Ethiopia. IRJAS. 2013;3:169-73.

67. Itanna F. Macro and micro-nutrient distributions in Ethiopian Vertisol landscapes. PhD thesis. University of Hohenheim, Germany. 1992. p. 202.

68. Alloway BJ. Zinc in soils and crop nutrition. International Fertilizer Industry Association and International Zinc Association, Brussels, Belgium and Paris. 2008. p. 21-2.

69. Asgelil D, Taye B, Yesuf A. The status of micro-nutrients in Nitisols, Vertisols, Cambisols and Fluvisols in major Maize, Wheat, Teff and Citrus growing areas of Ethiopia. In: Proceedings of Agricultural Research Fund, 2007. p. 77-96.

70. Bereket $\mathrm{H}$, Tjeerd-Jan S, Ellis H. Teff (Eragrostis tef) production constraints on Vertisols in Ethiopia: farmers' perceptions and evaluation of low soil zinc as yield-limiting factor. Soil Sci Plant Nutr. 2011;5:587-96.

71. Jiri Z, Pavel N. Comparison of some soil extractant for determination of Boron. Commun Soil Sci Plant Anal. 2009;40:96-105.

72. de Waldemar ON, Antonio SM, Maria AG, Cesar C, Clovis MB. Boron extraction and vertical mobility in Parana state Oxisol. Brazil R Bras Ci Solo. 2009;33:1259-67.

73. Joshi C, Srivastava PC, Pachauri SP, Shuka AK. Evaluation of different soil extracts for assessing boron availability to maize (Zea mays L.). SJSS. 2014;4:254-63.
74. Engel RE, Zubriski JC. Nitrogen concentrations in spring wheat at several stages of growth. Commun Soil Sci Plant Anal. 1982;13:531-44.

75. Jaroslaw S. Applicability of different indices to evaluate nutrient status of winter wheat in the organic system. J Plant Nutr. 2007;30:351-65.

76. Plank CO, Donohue SJ. Reference sufficiency ranges for plant analysis in the southern region of the United States. Southern Cooperative Series Bulletin \#394, 2000. p. 29-32.

77. Jones J, Wolfy B, Miller HA. Plant analysis hand book. Athens: Micro-Macro publishing Inc.; 1991.

78. Astatke A, Mamo T, Peden D, Diedhiou M. Participatory on-farm conservation tillage trial in the Ethiopian highlands: the impact of potassium application on Vertisols. Exp. Agri. 2004;40:369-79.

79. Subba RA, Srivastava S. Assessment of potassium availability in Vertisols and its implication on fertilizer K recommendation. In: 7th IPI-FAI round table in collaboration with IPNI, Theme: Reinforcement of $\mathrm{K}$ recommendations in Vertisols. 20 March, 2012. New Delhi, India. 2012. p. 13-7.

80. Mitchell CC, Huluka G. Critical Soil Test Values (For P, K, Mg and Ca). In: Agronomy and Soil Series. Alabama Agriculture Experiments Station, Auburn University, Alabama. Vol. S-02-11, 2011. p. 2.

81. Vitosh M L, Johnson JW, Mengel DB. Tri-state fertilizer recommendations for corn, soybeans, wheat and alfalfa. In: Purdue Forage Information. Vol. 2013. Purdue University, Cooperative Extension Service, West Lafayette, Indiana. 2007.

82. Melgar R, Magen H, Camozzi ME, Lavandera J. Potassium chloride application in wheat in pampean region, Argentina. Response to potassium or chloride? 2001. p. 6-10. http://www.iclfertilizers.com/Fertilizers/Knowledge\%20Center/KCl_application_in_wheat_in_Argentina.pdf. Accessed on 16 Mar 2015.

\section{Submit your next manuscript to BioMed Central and take full advantage of:}

- Convenient online submission

- Thorough peer review

- No space constraints or color figure charges

- Immediate publication on acceptance

- Inclusion in PubMed, CAS, Scopus and Google Scholar

- Research which is freely available for redistribution

Submit your manuscript at

www.biomedcentral.com/submit

C Biomed Central 